\title{
3D model and morphometry of the Beringin watershed as an effort for flash flood disaster risk reduction in Semarang
}

\author{
Ariyani Indrayati ${ }^{1, *}$, Ananto Aji ${ }^{1}$, and Nur 'Izzatul Hikmah ${ }^{1}$ \\ ${ }^{1}$ Geography, Geography Department, Semarang State University, 50229 Semarang, Indonesia
}

\begin{abstract}
The Beringin watershed is one of the watersheds (DAS) located in Semarang, Central Java, Indonesia. During 2010 - 2017 in this watershed area, there have been 8 flood disasters, the last two of which changed from an inundation flood to a flash flood type. The objective of this research is to investigate the characteristics of the rivers or the morphology of the watershed by 1) creating a three-dimensional spatial model of the Beringin watershed and describing its physical profiles and shapes, 2) arranging a satellite imagery map of the settlement at risk of flash flood disaster surrounding the watershed, 3) mapping the morphometric of the watershed, which consists of the landslide potential, the narrowing of river bodies and calculating the peak discharge in order to get the trigger factor of the flash flood, and 4) mapping the vulnerability of the Beringin watershed to minimize the flash flood disaster risk. The research method conducted was a combination of qualitative and quantitative approaches. Clearly, that the output of this research will contribute to the conservation of the Beringin watershed whose outcome is the reduction of the flash flood disaster risk affecting the communities surrounding the Beringin watershed.
\end{abstract}

\section{Introduction}

The Beringin watershed is one of the watersheds located in Semarang, Central Java, Indonesia. During 2010 2017 in this area, there have been 8 flood disasters, the last two of which changed from an inundation flood to a flash flood type. The prevalence of the flooding is mostly in the rainy season. The frequent flooding phenomenon in the watershed is due to the large discharge and flooding in the area around the estuary, the encounter of several streams, and the water channel blockage. The blockage can be caused by garbage, sedimentation, tree debris, and the water vegetation. The flooding is caused by the massive accumulation of water in a short period of time which is not accompanied by the ability to discharge a certain amount of water at the same rate. The water is accumulated because of the small soil absorption, the large basin area or the obstruction of water mass by certain obstacles.

The communities around the watershed relatively build their houses adjacent to the river, some even are located on the banks of the river. Suharini stated that the location of the settlements on the river banks which are dirty areas worsen the situation that is naturally prone to flood disasters. It can be seen from the amount of garbage scattered in the river body and the sedimentation in the bending part of the river [1]. The people living around the area are mostly the victims of the flood disaster which cause the damage and even destruction of their houses, the loss and damaged property, the declining state of the household economy, and several diseases, such as itching and coughing colds.

Among the flood disasters that have occurred in the Beringin watershed during 2010-2017, two of them were identified to change from an inundation flood to a flash flood type. Flood is defined as the overflow of the river current as the water exceeds the river capacity. Therefore, it overflows and inundates the surrounding plains or lower areas. This inundation flood type turned into a flash flood. A flash flood is the result of highintensity rainfall within a short duration which causes the river flow to rise rapidly [2].

Unfortunately, the communities understanding of the river characteristics, particularly those associated with flash floods is still low. A flash flood is one type of flood disasters that need to be constantly watched by the community. Characteristics of the flood are come suddenly and also recede quickly give a great impact on the people living in the downstream areas. The communities need to be prepared for facing the threat of flash flood disaster through the improvement of their capacities [3]. Prior research results on the community preparedness in the Beringin watershed [4] indicated a change in their preparedness such as disaster understanding, resource mobilization, flash flood early warning system, and preparedness planning.

\section{The material and method}

The research was conducted with a combination of qualitative and quantitative approaches. To achieve the first and second objectives, the researchers used a qualitative approach by interpreting the digital map and satellite images to find the watershed boundary. To create a 3-dimensional model, a digital image processing (Aster) was done by entering the elevation data (Digital Elevation Model).

Corresponding author: ariyani.ideas@gmail.com 
The second objective was obtained by overlaying the result of the image interpretation onto the administrative map resulting in the image of the target of the settlement at risk of the flash flood. The geospatial secondary data which include topographic maps of 1:25.000 scale. The TM satellite images were used to detect the land use, the disaster-prone areas, and the population distribution in disaster-prone areas.

The third and fourth objectives were achieved using a quantitative approach. The quantitative approach conducted in the study means analyzing numbers [8] including the data of the rainfall and the population, while the social and economic data obtained from the Central Bureau of Statistics (BPS) were used to describe the profile of people living in the flash flood-prone areas.

The next steps were calculating the potential of landslides, the peak flood discharge, and the measurement of river morphometric using a GPS tracking and measuring the narrowing of the river body to know the trigger factor of the flash flood. The investigation started from the upstream rivers in the onetiered Beringin rivers. The measurements on the morphometrics of the rivers were carried out primarily in the locations where the narrowing of the river bodies is found, either caused by a sedimentation, natural plants or human waste disposal.

The field observations and measurements were also carried out to obtain data related to the landslides that precede the occurrence of the flash flood. The researchers applied a field approach to obtain the landslide-related data. The field is a plot of land considered as a complex of the physical properties of the surface and near the surface [17]. A terrain unit is an ecological unit. In these ecological units the forms, processes, rocks, soil, water, and vegetation are interconnected with each other resulting in a balanced nature [17].

The assessment of the various field characteristics was carried out by means of deforestation. The classification determination of the field suitability is based on the lowest to the highest values. The interval was obtained from the highest number of digits reduced by the lowest number divided by the number of classes.

The physical conditions observed in the field were the slant of the slope, the flood basin areas, the groove erosion zones and the gully erosions as well as the cracking zones both in the form of folds and fractures which are the forerunners of the landslide occurrences on the earth surface. The hilly relief causes a greater possibility of landslide disasters. Moreover, there were found groove erosion and gully erosion zones that have higher runoff speed.

The gully erosion is the continuation of the groove erosion where the grooves are wider and in the form of trenches, the depths of which can reach 1 to 2.5 meters or more [5]. If the erosion is not anticipated, it may cause landslides that can damage or amass all objects on their paths. The rainfall data were obtained from the Meteorology Climatology and Geophysics Board (BMKG) to know the rainfall patterns and the peak discharge pattern as the causes of the flood.
The fourth objective was obtained by elaborating the results achieved in the previous three objectives to obtain the priority zonation map of flash flood conservation in Beringin watershed. It is clear that the output of this research will contribute to the conservation of the Beringin watershed whose outcome is the reduction of flash flood disaster risks in the affected communities around it.

\section{Result and discussion}

Astronomically, the Beringin watershed lies between $110^{\circ} 17^{\prime} 30^{\prime \prime} \mathrm{E}-110^{\circ} 21^{\prime} 100^{\prime \prime} \mathrm{E}$ and $7^{\circ} 4^{\prime} 00^{\prime \prime} \mathrm{S}-6^{\circ} 50^{\prime} 00^{\prime \prime} \mathrm{S}$. Geographically, it flows from its upstream in the south and flows downstream to the north and empties into the Java Sea. It is bordered by the Plumbon watershed in the west and by the Garang watershed in the east. Administratively, the Beringin watershed is located in Semarang City, Central Java province, Indonesia covering several sub-districts in Mijen, Ngaliyan, and Tugu districts.

The villages located in the three sub-districts are not entirely located around the Beringin watershed. For example, the Beringin river, hydrologically, only pass the Mangunharjo and Mangkang Wetan villages since the river have been permanently banked on the left and right sides, and they receive the overflow in case of flooding.

Table 1 shows that only Desa Beringin and Desa Gondoriyo are entirely located in the Beringin watershed while the other sub-districts have some areas outside the Beringin watershed.

Table 1. Villages in Beringin watershed

\begin{tabular}{clc}
\hline No & \multicolumn{1}{c}{ Village } & $\begin{array}{c}\text { Large of village in } \\
\text { Beringin Watershed } \\
\left(\mathbf{K m}^{\mathbf{2}}\right)\end{array}$ \\
\hline 1 & Purwosari & 0,02 \\
2 & Tambangan & 0,01 \\
3 & Mijen & 1,77 \\
4 & Jatibarang & 1,58 \\
5 & Kedungpane & 2.80 \\
6 & Pesantren & 3,79 \\
7 & Podorejo & 0,55 \\
8 & Wates & 2,97 \\
9 & Beringin & 4,60 \\
10 & Ngaliyan & 2,44 \\
11 & Bambankerep & 0,24 \\
12 & Tambakaji & 1,07 \\
13 & Gondoriyo & 5,33 \\
14 & Wonosari & 2,90 \\
15 & Mangkang Wetan & 0,26 \\
16 & Mangunharjo & 0,03 \\
\hline & Total & 30,36 \\
\hline
\end{tabular}

Source: RTRW Kota Semarang 2011-2031

\subsection{Spatial and social profiles in the Beringin watershed}

The Beringin river spatial profile can be described by looking at its following physical conditions. It is one of the rivers that flow in the west Semarang areas, starting from Mijen sub-district and Ngaliyan sub-district and emptying in Tugu sub-district (flowing to the north Java 
Sea). The length of the river reaches approximately 22.5 $\mathrm{km}$ with its watershed width of $30.36 \mathrm{~km}^{2}$. Topographically, the Beringin watershed has hilly conditions in the upstream areas and has a flat slope characteristic in the downstream areas with soil elevation approaching the sea level elevation that will complicate the discharge of water in the case of tides.

The width of the Beringin river approaching the downstream, like in Mangunharjo on the national road bridge area, is 20 meters and gradually constricts towards the estuary to 9.5 meters width. Viewed from its shape, the Beringin river is an elongated river which in the upstream has a wide watershed shape whereas the downstream tends to narrow. Some facts indicate that water flowing in the narrowing downstream areas often causes overflow because the water cannot be accommodated by the river. Thus, in this area, there are a more frequent overflow floods than in other areas, with the inundation depth generally approximately reaches 0.5 meters and the inundation duration can be up to two days.

However, the facts show that there has been a change of flood type from the local inundation flood into the flash flood in the last two flood events. Geographically, the locations affected by the flash flood are located relatively close to the upstream. The observations conducted in the Beringin watershed, in the upstream areas revealed that there has been an opening of new land for housing thus reducing the absorption ability of the area to retain the rainwater. As a result, much of the rainwater flows quickly to the river which increases the river current debt in the Beringin river tributaries. The massive surface runoff in small rivers accompanied by the erosion in the upstream areas, which then resulted in the sedimentation in the narrow section of the river, triggering the occurrence of a flash flood.

The high-intensity rainfall in the upstream areas increases the river water volume. The water flowing to the downstream areas is not accommodated and eventually overflows. Similarly, continuous rains for a long period of time in the downstream areas can also cause an inundation in the river plains. The rainfall obtained from Wonosari station in Beringin watershed can be seen in Table 2 .

Table 2. Rainfall data

\begin{tabular}{lccccc}
\hline \multirow{5}{*}{ Month } & \multicolumn{5}{c}{ Wonosari Rainfall Station } \\
\cline { 2 - 6 } & 2009 & 2010 & 2011 & 2012 & 2013 \\
\cline { 2 - 6 } Jan. & 294 & 439 & 367 & 662 & 634 \\
Feb. & 676 & 291 & 164 & 346 & 329 \\
March & 100 & 277 & 135 & 234 & 90 \\
April & 229 & 234 & 191 & 193 & 212 \\
May & 265 & 417 & 147 & 88 & 148 \\
June & 92 & 273 & 28 & 126 & 320 \\
July & 9 & 46 & 17 & 14 & 191 \\
August & 0 & 0 & 0 & 0 & 33 \\
Sept. & 20 & 188 & 57 & 8 & 0 \\
Okt. & 1 & 152 & 74 & 161 & 101 \\
Nov. & 194 & 233 & 274 & 194 & 151 \\
Dec. & 91 & 344 & 196 & 287 & 230 \\
\hline Source: Berinyyyy
\end{tabular}

Source: Beringin Watershed Rainfall Station

Generally, it can be said that the rainfall in the Beringin watershed tends to increase annually. The highest rain intensity is from December to February. The rain in these months is destructive to soil and it can trigger the erosion and landslide occurrences. It is known that flash floods are always preceded by the landslide around the river body.

The slant of the Beringin watershed slope varies from being flat $(0-2 \%)$, ramp (2-15\%), rather steep (15-25\%), and steep $(25-40 \%)$, as seen in Table 3 of slope class. From the various classes in the Beringin watershed, there is a flat slope $(0-2 \%)$ which covers an area of $4.17 \mathrm{~km}^{2}$ located in three sub-districts, namely Ngaliyan, Tugu, and Mijen sub-districts. In more detail, when viewed at the village level, the distribution of the flat slopes located in Ngaliyan sub-district covers Wates and Gondoriyo villages. The slope in a flat category in Mijen sub-district includes Mijen, Jatibarang, Kedungpane, Pesantren villages. While in Tugu sub-district, it covers Mangkang Wetan and Mangunharjo villages.

The distribution of ramp slope category (2-15\%) covering $17.93 \mathrm{~km}^{2}$ spread in Ngaliyan sub-district includes Bambankerep, Wates, Podorejo, Ngaliyan, Beringin, Tambakaji, and Gondoriyo villages while in Mijen sub-districts includes Tambangan, Purwosari, Mijen, Pesantren, and Kedungpane villages. The rather steep slope category (15-25\%) covering an area of 6.71 $\mathrm{km}^{2}$ which is spread in Ngaliyan sub-district includes Bambankerep, Ngaliyan, Beringin, Tambakaji, Gondoriyo, Wonosari, and Podorejo villages while in Mijen sub-districts covers Kedungpane village.

The slant of the Beringin watershed slopes is dominated by ramp slopes with a $2-15 \%$ classification which is $17.93 \mathrm{~km}^{2}$ wide. The ramp slopes cause the Beringin watershed to be a flood disaster-prone area. The topographic conditions in Ngaliyan sub-district have a relatively similar slope slant with that of Mijen subdistrict, ranging from $2 \%-40 \%$. Tugu sub-district is located closer to the coastline (downstream area) with most of the land is used as settlements. The slope slant conditions that can result in the overflowing flood are flat slopes with a $0-2 \%$ which are adjacent to the outlet or sea that has the potential for flooding. It is evident in the downstream areas of the Beringin river.

The overflow that occurs in the downstream of the Beringin river is also caused by narrowing of the river body. The narrowing river width causes a very large volume of water flowing from the upstream unable to be accommodated by the river. As a result, the water overflows and inundates the surrounding lower areas. When the inundation gets bigger, it will result in floods in the downstream areas of the Beringin river.

Table 3. The classification of slope slant in the Beringin watershed

\begin{tabular}{cccc}
\hline No & Slope (\%) & Classification & Large $\left(\mathbf{K m}^{\mathbf{2}}\right)$ \\
\hline 1 & $0-2$ & Flat & 4,17 \\
2 & $2-15$ & Ramps & 17,93 \\
3 & $15-25$ & Rather Steep & 6,71 \\
4 & $25-40$ & Steep & 1,55 \\
\hline & Total & & 30,36 \\
\hline
\end{tabular}

Source: RTRW Kota Semarang 2011-2031 [7].

The steep slope class (25-40\%) of $1.55 \mathrm{~km}^{2}$ wide spreads in Ngaliyan sub-district covering Bambankerep, 
Ngaliyan, Beringin, Gondoriyo, and Wonosari villages. Although this steep slope region is not very wide, it also holds another potential hazard, i.e. the landslide disaster. The land material landslide carried to the river body later forms a natural dam on the narrowing river body. When the natural dam is collapsed, a flash flood will occur.

The social profile of Beringin river can be illustrated by looking at the conditions of the land use as a result of human cultivation and flash flood-prone housing. The development of urban activities in Beringin watershed is different among the three sub-districts surrounding it in terms of the land use. Generally, the land use in Mijen sub-district is oriented for rural activities. The urban land use is spread across the central areas of activity and along the roads. Areas that have a quite rapid land development are among others around the urban areas and trade services in the villages of Wonopolo, Mijen, and Cangkiran. The change of land use from undeveloped to being developed is high in the area.

Table 4. Land use of the Beringin watershed

\begin{tabular}{llrr}
\hline No & Land Use & Width $\left(\mathbf{k m}^{2}\right)$ & $\begin{array}{c}\text { \% from } \\
\text { Watershed } \\
\text { Width }\end{array}$ \\
\hline 1 & Forest & 0,12 & 0,39 \\
2 & Cultivation & 24,60 & 81,04 \\
3 & Settlement & 1,36 & 4,45 \\
4 & Swamp & 0,15 & 0,42 \\
5 & Rice Field & 1,88 & 6,19 \\
6 & Dry Field & 2,25 & 7,41 \\
\hline & Total & 30,36 & 100 \\
\hline
\end{tabular}

Source: RTRW Kota Semarang 2011-2031 [7].

Most of the land use in Ngaliyan and Tugu subdistricts is for urban purposes. The high-scale processing industry activities become the factors causing the rapid growth in the region. The distribution of the urban areas is located in the area directly adjacent to the SemarangKendal Pantura (North Coastal of Java) Highways and close to transportation service centers such as the Ahmad Yani Airport and the harbors.

Based on Table 4, it can be seen that the land use in the Beringin watershed covers $81.04 \%$ for cultivations, followed by $7.41 \%$ for drylands, $6.19 \%$ for rice fields, $4.45 \%$ for settlements, $0.63 \%$ for swamps and $0.42 \%$ for forests. The largest use of land is $81.04 \%$ for cultivations and the smallest land use is for swamp at $0.42 \%$.

The land use conditions on the banks have gradually changed into a developed land. The increased land use changes may result in the decreasing ability of the land to absorb water, thus increasing the surface runoff and causing flooding. In fact, there is a lot of garbage collected on the river body. This shows that the public lack awareness that these garbage piles can narrow down the watershed area. Consequently, the risk of flood events will continue to increase.

The population around the Beringin watershed as well as the total area of villages included in the Beringin watershed area can be seen in Table 5. The total population around the Beringin watershed can be analyzed by the comparison of the existing village areas with that of the villages that are included in the Beringin watershed area. The total population of the villages that are included in the Beringin watershed in 2009 was 83,535 people. The largest population is in Tambak Aji village and the fewest are in Pesantren village.

Table 5. Existing population in the Beringin watershed

\begin{tabular}{llrcc}
\hline No & Village & $\begin{array}{c}\text { Total } \\
\text { Population } \\
\text { (people) }\end{array}$ & $\begin{array}{c}\text { Existing } \\
\text { Village } \\
\text { Width } \\
\text { (family) }\end{array}$ & $\begin{array}{c}\text { Population } \\
\text { Density } \\
\text { (people/Ha) }\end{array}$ \\
\hline 1 & Wates & 3.911 & 382 & 10,24 \\
2 & Beringin & 12.150 & 125 & 97,20 \\
3 & Ngaliyan & 12.373 & 528 & 23,43 \\
4 & Tambakaji & 20.102 & 383 & 52,49 \\
5 & Gondoriyo & 4.778 & 371 & 12,88 \\
6 & Wonosari & 16.943 & 323 & 52,46 \\
7 & Jatibatang & 2.641 & 227 & 11,63 \\
8 & Kedungpane & 4.720 & 583 & 8,10 \\
9 & Pesantren & 948 & 680 & 1,39 \\
10 & Mijen & 4.969 & 474 & 10,40 \\
\hline & & \multicolumn{3}{c}{ Average } \\
\hline
\end{tabular}

Source: Village Monograph, 2009 [11].

\subsection{Beringin watershed morphometric}

Morphometric is the quantitative value of the parameters contained in a watershed. The watershed morphometric parameters include the watershed borders and width, the length of the main river, the river orders, and the drainage density level. The watershed borders depicted in the river network map is artificial since, in reality, the borders are not visible in the field. Although they are not visible, the borders limit the amount of rainfall in the areas. The large watershed borders are composed of several sub-watersheds, and the sub-watershed may be composed by several sub-sub-watersheds.

The amount of rainfall received by a watershed depends on the watershed's width and on the border firmness among the watersheds. The larger the watershed is, the greater the peak discharge it will receive. In addition to its width, the peak discharge can be predicted from the watershed forms. Assuming that the rainfall intensity and the width and the topography of the two watersheds are the same but the watershed forms are different (i.e. long and round), the flow characteristics can be relatively comparable. A long watershed form will have a longer peak time than the rounded one, while the round-watershed discharge is larger than that of the long one. The illustrations of various forms of watersheds along with their peak discharges are illustrated in the form of flow hydrograph curves.

The river order is the serial number of each river segment to its main river. The Strahler method is the most widely used method to determine the river order. Strahler's $1^{\text {st }}$ order rivers are the tributaries that are located at the far end and considered as the first fountain of the tributaries. The river segment which is a result of a meeting of rivers at the same order is a $2^{\text {nd }}$ order river, and the river segment as the result of the meeting of two rivers of different orders will be categorized as the higher order. Other methods of determining the river orders are Horton, Shreve, and Scheidegger methods.

The length of the main river as the third morphometric in this study will show the size of the 
watershed and the slant of the main river which is more or less identical to that of the watershed. The main river inclination will affect the current velocity. It means that the higher the main river slant is, the faster the flow of the water in the watershed reaches the outlet or the shorter the concentration-time it takes.

The main river and its tributaries form a certain flow pattern. The total length of overall river channels divided by the area of the watershed is called the drainage density. Linsley (1982 in Tikno, 1996) [13] states that the drainage density is related to the level of inundation. If the watershed has a density value of less than 1 , it indicates that the watershed is often flooded or has a poor drainage. However, if the drainage density is $1-5$, it indicates that the watershed is never inundated or has good drainage.

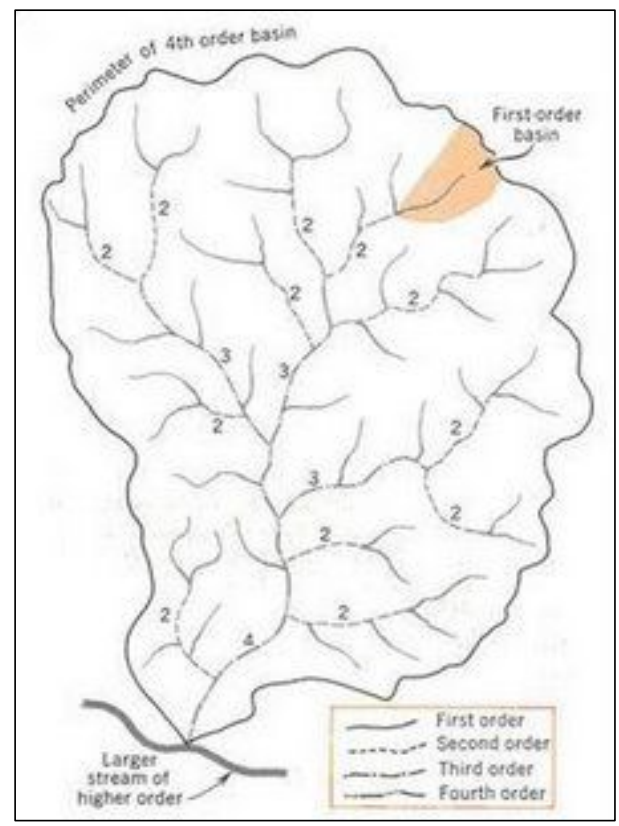

Fig. 1. The determination of river order using the strahler method (Strahler, 1975)

According to Asdak (2001) [16], there are several factors that influence the amount of surface flow or runoff, such as the morphometric size, the topography, the geology and the land use (species and vegetation density) of the watershed. Judging from the size of the watershed, it can be concluded that the watershed has a high flow volume of runoff and a big runoff flow. However, the runoff volume and its rate per unit area in the Beringin watershed is small.

The watershed width reflects the amount of rainfall it receives. A bigger watershed tends to receive greater rainfall. Nevertheless, the time difference or lag between the rain peak and the hydrograph flow peak becomes longer. Similarly, the time required to reach the hydrograph peak and the length of time for the overall hydrograph flow also becomes longer.

The slant of the watershed affects the hydrograph behavior in terms of timing. If the watershed slant is large, the water runoff rate is faster. Seen from its slant level, the Beringin watershed has a considerable slant. The slant level of the watershed (0.3) results in higher water runoff rates in the Beringin watershed than that of other nearby watershed rates, which have smaller slant levels.

The drainage density is also the most important factor in determining the speed of the water runoff. If the area has a high density, it has a quick runoff speed with the same rainfall rate. With the high flow density, the peak discharge will be achieved faster. The Beringin watershed, having a small drainage density, i.e., 2.08 $\mathrm{mile} / \mathrm{mile}^{2}$, has the lowest runoff compared to the other two flats that flank it.

Table 6 is a morphometric calculation of the Beringin watershed. The morphometric data specified include 10 watershed morphometrics, including the river length, the watershed area, the watershed circumference or perimeter, the drainage density (Dd), the center of gravity $(\mathrm{Cg})$, the slant of basin $(\mathrm{Sb})$, the river length to the center of gravity (Lca), the slant of river, the width of watershed and the form factor of watershed $(\mathrm{k})$.

The Beringin watershed is a large watershed with many first-order rivers and its largest river order is 6 . In this research, the river orders are determined based on Strahler's method. The largest river order in the Beringin watershed is 5 . The circumference or perimeter of the Beringin watershed is 117.67 each. The drainage density or Dd found in the Beringin watershed are 3.93 and 2.08 mile/ mile $\mathrm{e}^{2}$. The slant of the watershed is 0.13 . For the form factor of the watershed, the Beringin watershed is 0.3184 or takes a shape of a leaf.

Table 6. The Beringin watershed morphometric

\begin{tabular}{|c|l|c|}
\hline No. & Morphometric & $\begin{array}{c}\text { Beringin } \\
\text { Watershed }\end{array}$ \\
\hline 1 & River Length $(\mathrm{Km})$ & 48.48 \\
& - Main & 232.19 \\
& - Order 1 & 118.66 \\
& - Order2 & 17.66 \\
& - Order 3 & 39.35 \\
& - Order 4 & 91.49 \\
& - Order 5 & - \\
\hline 2 & - Order 6 & 240.14 \\
\hline 3 & Watershed Width $\left(\mathrm{Km}^{2}\right)$ & 117.67 \\
& (Km) & 2.08 \\
\hline 4 & Drainage Density (mile/mile $\left.{ }^{2}\right)$ & \\
\hline 5 & Center of Gravity $(\mathrm{Cg})$ & 417806 \\
& - x & 9221550 \\
\hline 6 & - y & 0.13 \\
\hline 7 & Whe slant of Basin $(\mathrm{Sb})$ & 18.19 \\
\hline 8 & Gravity (Lca) $(\mathrm{Km})$ & \\
\hline 9 & Slope of River & 0.53 \\
\hline 10 & Watershed Width $(\mathrm{Km})$ & 2.63 \\
\hline
\end{tabular}

Source: Map analysis and calculation, 2018

A landslide can be interpreted as the moving of a number of rock or soil materials to a lower area since the material durability is smaller than its displacement. Rain, gravity, earthquakes or great pressure by the vehicle give force that can move the materials.

The landslide in the Beringin Watershed mostly occurs on steep slopes $(>300)$. There are thin weathered layers on the top, but the bottom is a thick hill $(>2 \mathrm{~m})$. There is a natural drainage channel due to the trench 
erosion from the top of the hill to the bottom. There is an impermeable layer at the bottom of the weathered layer.

The data from Prosperity of Development and Protection of Society (Kesbanglinmas) state that some villages in the Beringin watershed area are prone to landslides. There have been several incidents resulting in casualties, both souls, and properties. Therefore, this threat needs to be watched. Early mitigation actions that can be undertaken are identifying areas and land characteristics which are prone to landslides, whether on a small scale or on a large scale. On a small scale, we can do an observation on the type of soil that is on the slopes with a large slant angle. While on a large scale, we can compare the characteristics of areas in which landslides have taken place with that of the observed area. This can be assisted by mapping landslide-prone areas derived from several thematic maps, such as geology, slopes, and soil.
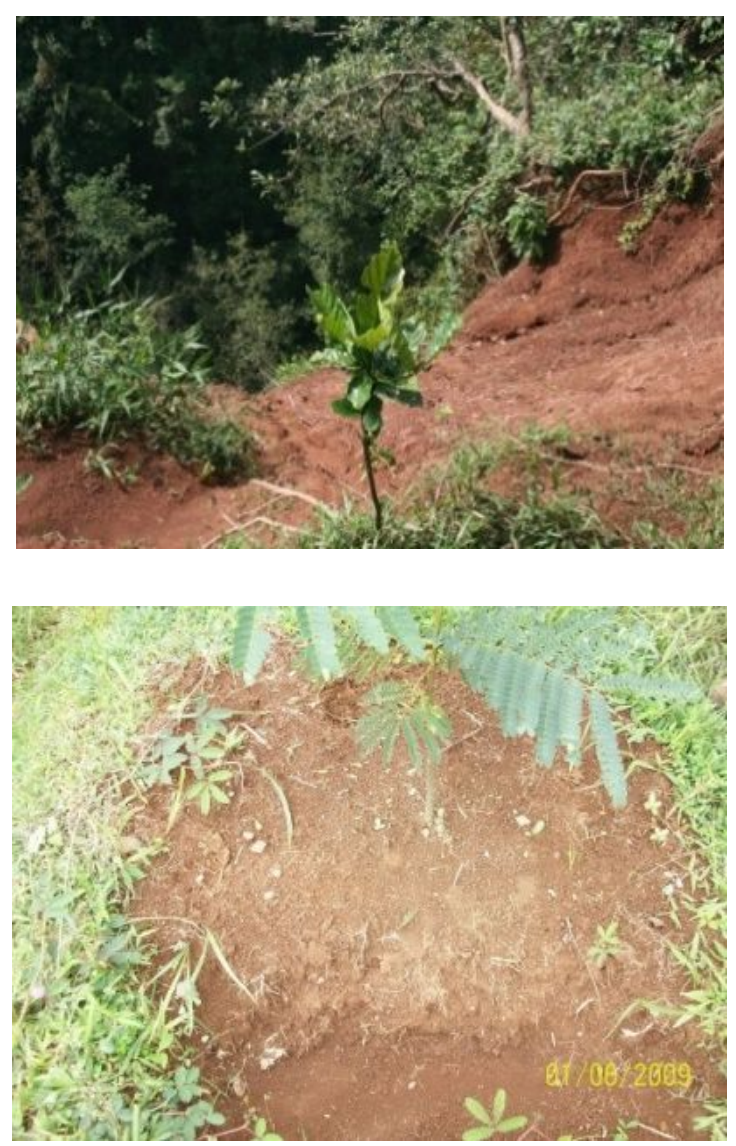

Fig. 2. Landslide events encountered during the field observation

\subsection{The triggers of flash floods in the Beringin watershed, Semarang}

The flash flood occurrences have the same cause [14] and [15] i.e. a high-intensity rain which occurs continuously in a quite long span of time (some days). The high-intensity rain is then accompanied by a landslide event on the steep slopes that border directly with the river body. The landslide brings with it including wood materials from fallen trees, rock materials and also garbage. All of these materials are then trapped in the narrowing river body, forming blockages and a kind of natural dam. When the rain continues producing runoff that fills the river bodies then the natural dam is no longer able to withstand the power of water discharge and river embankment. Subsequently, a flash flood takes place.

Understandably, the trigger of the flash flood is the landslide around the narrowing river body. This flash flood is characterized by a sudden overflowing in which water overflows very rapidly around the river body with a very powerful blow, making it more destructive than an overflowing flood. After that, the water runoff from this flash flood will recede quickly. This kind of flood recedes more quickly than an inundation flood that occurs due to an overflow.

Because one of the triggers of a flash flood is the narrowing of the river body, it is very important to map the locations on the river body where the narrowing takes place. This narrowing can occur due to the natural materials that are accumulated due to the sedimentation of eroded materials in a long time, also the sedimentation of landslide materials. The narrowing of the river body can also occur as a result of human activities that litter carelessly into the river. The following Table 7 shows locations where the river bodies are narrowed in the Beringin watershed.

Table 7. The Locations of River Body Narrowing in the Beringin River

\begin{tabular}{|c|c|c|c|c|}
\hline NO & Coordinate & $\begin{array}{c}\text { River } \\
\text { Width } \\
\text { (Meter) }\end{array}$ & $\begin{array}{c}\text { Narrowing } \\
\text { Width } \\
\text { (Meter) }\end{array}$ & $\begin{array}{c}\text { Narrowing } \\
\text { Length } \\
\text { (Meter) }\end{array}$ \\
\hline 1 & $\begin{array}{c}7^{\circ} 0^{\prime} 10.58^{\prime \prime} \mathrm{S} \\
110^{\circ} 20^{\prime} 2.06^{\prime \prime} \mathrm{E}\end{array}$ & 4.1 & 2,7 & 3 \\
\hline 2 & $\begin{array}{c}6^{\circ} 59^{\prime} 59.98^{\prime \prime} \mathrm{S} \\
110^{\circ} 19^{\prime} 48.91^{\prime \prime} \mathrm{E}\end{array}$ & 4.2 & 2.5 & 2 \\
\hline 3 & $\begin{array}{c}7^{\circ} 0^{\prime} 10.12^{\prime \prime} \mathrm{S} \\
110^{\circ} 20^{\prime} 21.16^{\prime \prime} \mathrm{E}\end{array}$ & 6.1 & 4.4 & 17.4 \\
\hline 4 & $\begin{array}{c}6^{\circ} 59^{\prime} 27.70^{\prime \prime} \mathrm{S} \\
110^{\circ} 19^{\prime} 15.84^{\prime \prime} \mathrm{E}\end{array}$ & 5.2 & 4.2 & 11 \\
\hline 5 & $\begin{array}{c}6^{\circ} 59^{\prime} 29.84^{\prime \prime} \mathrm{S} \\
110^{\circ} 19^{\prime} 14.86^{\prime \prime} \mathrm{E}\end{array}$ & 5.2 & 2.5 & 2 \\
\hline 6 & $\begin{array}{c}6^{\circ} 59^{\prime} 16.42^{\prime \prime} \mathrm{S} \\
110^{\circ} 18^{\prime} 59.93^{\prime \prime} \mathrm{E}\end{array}$ & 7.1 & 3 & 3.5 \\
\hline 7 & $\begin{array}{c}6^{\circ} 59^{\prime} 28.09^{\prime \prime} \mathrm{S} \\
110^{\circ} 18^{\prime} 28.64^{\prime \prime} \mathrm{E}\end{array}$ & 3.35 & 1.1 & 1.5 \\
\hline 8 & $\begin{array}{c}6^{\circ} 59^{\prime} 24.34^{\prime \prime} \mathrm{S} \\
110^{\circ} 18^{\prime} 43.15^{\prime \prime} \mathrm{E}\end{array}$ & 3.1 & 3.1 & 0,5 \\
\hline
\end{tabular}

Source: A Field Survey of Indrayati. A., et.al., 2018.

The measurement results from the Beringin river can be read in Table 7 . The field measurements and observations of the sedimentation results in the locations where the narrowing of the Beringin river takes place are carried out by exploring the river body starting from the upstream areas consisting of the first order rivers. The sample points have also been identified in advance based on the map interpretation of the river body that is directly connected to the slopes that are prone to landslides. 
The results of a survey that has been conducted in seven locations in Beringin and Gondoriyo villages show the different results of field measurements.

1) The $1^{\text {st }}$ location is astronomically located at $7^{\circ} 0^{\prime} 10.58^{\prime \prime S}$ and $110^{\circ} 20^{\prime} 2.06^{\prime \prime} \mathrm{E}$ and is administratively located in Permata Sentosa Housing area, Beringin village, Ngaliyan sub-district, Semarang. In general, there are two conditions of the river, i.e. it flows in the settlement area and it flows outside the settlement area. The rivers which flow the settlement area are relatively below the land surface and are covered by a building construction. At some points, the rivers are still open with fortified banks. In this case, the narrowing is not extreme as the fortified banks reduce the risk of landslides from both sides, but this embankment itself leads to the narrowing of the river width.

2) The $2^{\text {nd }}$ location is located in a settlement area but outside a housing complex area, which is at $6^{\circ} 59^{\prime} 59.98^{\prime \prime} \mathrm{S}, 110^{\circ} 19^{\prime} 48.91^{\prime \prime} \mathrm{E}$. Its condition is similar to that of the first location. The rivers flow is characterized as having low flow rates. The vegetation that dominates around the riverside is shrubs and grass. At some points, we can see the narrowing the river width which derived from the sedimentation of materials carried by the current/ small rocks that erode from the riverbanks and shrubs that collapsed in the middle of the river. During the field observation, the depth of the river was approximately $10 \mathrm{~cm}$ above the ankles of adult people, the river width was only about 1.5 meters. On both sides of the river were banana plants which were not wellattended or grew wild.

3) The $3^{\text {rd }}$ location is astronomically located at $7^{\circ} 0^{\prime} 10.12^{\prime \prime S}$ and $110^{\circ} 20^{\prime} 21.16^{\prime \prime} \mathrm{E}$ and is one kilometer north of Permata Sentosa Housing, Beringin village, Ngaliyan sub-district, Semarang. Based on the field conditions, the narrowing is quite large. The width of the river was originally $6.1 \mathrm{~m}$ and the narrowing itself is 4.4 $\mathrm{m}$ wide and reaches $17.4 \mathrm{~m}$ long which are found in both sides of the river. The materials are household waste, land sedimentation, and eroded materials from both sides of the river. The considerable amount of household waste contained in the river is because it becomes the sewage channel from some residents' houses. Besides, there are plants that grow on the sediment of the river which also contributes to the narrowing of the river.

4) The $4^{\text {th }}$ location is astronomically located at $6^{\circ} 59^{\prime} 27.70^{\prime \prime} \mathrm{S}$ and $110^{\circ} 19^{\prime} 15.84 " \mathrm{E}$. The location of the measurement is not really into the upper stream of the river, but it tends to be closer to the confluence of its tributary. The land around the river is used for developing settlements [12] and bamboo plants. The narrowing that occurred in this location is quite large due to the collapse of the cut-down bamboo trees that cover the flow. The river is $5.2 \mathrm{~m}$ wide and $11 \mathrm{~m} \mathrm{long}$, the visible narrowing covers most of the river leaving about $1 \mathrm{~m}$ of the river to flow. According to the information from the residents interviewed in the field, the river gets narrower because of the concrete embankment at some points. In addition to that, the toll road development in the region also plays a role in narrowing the river. It can be seen in the area that the highway bridge construction does not pay much attention to the river capacity as the flood discharge increases. According to some informants, the river overflowed because of floods caused by the highway bridge construction in 2010. A monitoring was also carried out in the deeper part of the upstream of the river and it was also found that in some locations the river got narrowing. However, the materials are the only sedimentation and fallen rocks from either side of the river.

5) The $5^{\text {th }}$ location is at $6^{\circ} 59^{\prime} 29.84^{\prime \prime} \mathrm{S}, 110^{\circ} 19^{\prime} 14.86^{\prime \prime} \mathrm{E}$. The narrowing that happened in some places is small in quantity respectively.

6) The $6^{\text {th }}$ location is astronomically located at $6^{\circ} 59^{\prime} 16.42 " \mathrm{~S}, 110^{\circ} 18^{\prime} 59.93$ "E. The last conditions showed that the narrowing of the river widths was considerable due to erosions on both sides of the river. The erosion was somewhat affected by the land management of the toll road development project located right in front of the site location. The width of the river was $7.1 \mathrm{~m}$ wide and narrowed to $3 \mathrm{~m}$ with a length of 3.5 $\mathrm{m}$. The land is mostly dry and vacant land, so along the two sides of the river, there are no trees that can effectively withstand the erosion rates. There are only shrubs and grasses.

7) The $7^{\text {th }}$ location is astronomically located at $6^{\circ} 59^{\prime} 28.09^{\prime \prime} \mathrm{S}$ and $110^{\circ} 18^{\prime} 28.64^{\prime \prime} \mathrm{E}$. Based on the field conditions, the river width was $3.35 \mathrm{~m}$ and narrowed. The narrowing is dominated by household waste. This is because the location is not far from the backyards of the settlement, so most residents choose to use the river as the sewage channel. Besides the household waste, the bamboo plants glowing in the middle of the river contribute to the narrowing the river. The condition of the river during the field observation showed that the water debt was low, so the narrowing was not too visible. The land around the river is used for bamboo plant vegetation and shrubs.

The $4^{\text {th }}$ to $7^{\text {th }}$ locations are administrative parts of Gondoriyo village, Ngaliyan Sub-District.

From the above description, it can be seen that the cause of the river body narrowing [9] are similar so that it can be classified [10] briefly into six (6) kinds. The narrowing is because the river is closed by the settlement and residential building construction, the concrete embankment at the edge of the river, the highway bridge construction project, the result of sedimentation of material carried by rainwater into the river (erosion) and land weathering caused by shrubs and the collapse of bamboo plants on the river banks which leads to higher sedimentation rates, landslides on the banks of the river, and the dumping of household waste by the people around the Beringin watershed which further worsens the narrowing of the river bodies. 
The results of the survey which is in the form of the description are then plotted into a 3D map of flash floodprone locations. It can be seen in Fig. 3.

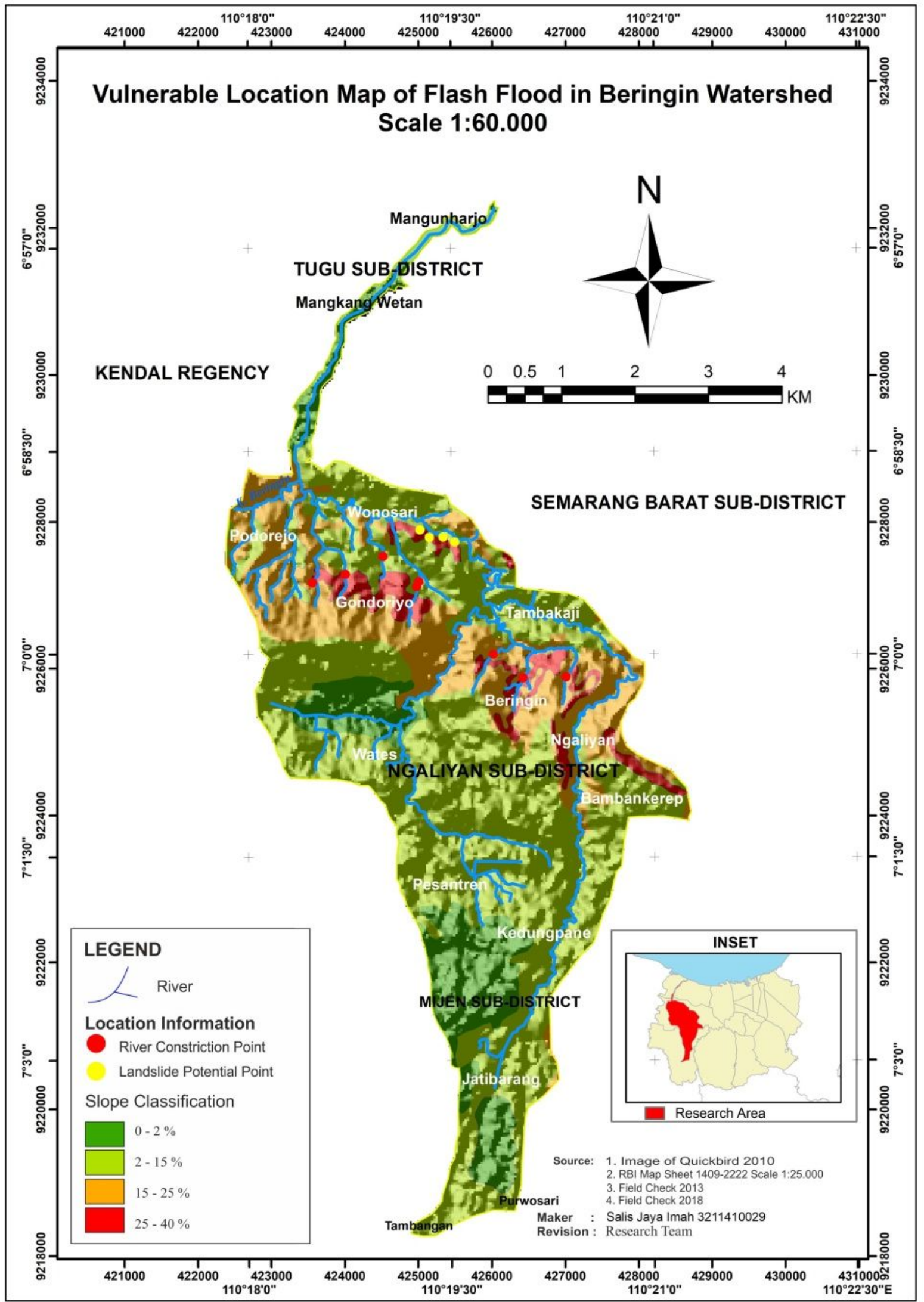

Fig. 3. Location of the narrowing of the Beringin river body 


\section{Conclusions}

The Beringin river spatial profile is well described after seeing its physical condition and social profile of the river. Generally, it can be said from its depicted physical condition, the area is naturally prone to flash flood. Socially, the land around the river body which is used for cultivation by the people and the settlements which are in the flash flood-prone areas are real risk factors. The geospatial-based data on the trigger of the flash flood disaster in the Beringin watershed, Semarang is fairly comprehensive, including its geospatial-based location and involving the community during the surveys. The map shows zones that need to be conserved which are around the red dots. The conservation is carried out by reducing the landslide threats and widening the river body by sedimentation dredging, and garbage clearance.

We would like to thank all of the research team who support this research and Bagus Adi Susilo and friends who have helped us in the field survey friend and made map revision in 2018 which was originally the work of Salis Jaya Imah in 2013 into a 3-dimensional mapping.

\section{References}

1. E. Suharini, "The development of Early Warning System Model for Flood Disaster which is based on Geographic Information System in the Beringin Watershed of Semarang", A research report of LP2M Unnes, Semarang, 2014.

2. E. Yulaelawati dan U. Syihab, Outsmarting Disasters, Presindo: Jakarta, Hal. 4 - 11, 2008.

3. Azmeri, Safrida, dan R. Mironi, "The Community Preparedness Management towards Flash Flood Disasters in Beureunut Village, Seulimum Subdistrict, Aceh Besar Regence," from a National Conference of Civil Engineering in 2016, ISBN: 2086-5244, 2016.

4. A.N Nurromansyah dan J.S Setyono, "The Preparedness Change of the Beringin Watershed of Semarang in Overcoming the Flash Flood Threat," A Regional and Environment Journal, vol. 2, no. 3, pages $231-244,2014$

5. H.C Hardiyatmo. The Landslide and Erosion Management, Gadjah Mada University Press: Yogyakarta, 2006.

6. A. Stahler. 1975. Physical Geography. New York: Sage.

7. Regional Regulation of Semarang, Number 14 of 2011 on Rural and Urban Planning in Semarang in $2011-2031$.

8. L.M Jannah, N. Safitri, B. Prasetyo dan M. Syarien, "Quantitative Approaches", Google Scholar: repository.ut.ac.id, 2014.

9. Barus dan Suwardjo. 1977. The Relationship between Rain Characteristics and Erosion, The $2^{\text {nd }}$ National Congress on Geology, Jogyakarta.

10. Julien, P.Y. 1995. Erosion and Sedimentation, $1^{\text {st }}$ ed. New York: Cambridge University.
11. E. Susilo dan B. Sudarmanto, "A Hydrology Study towards the Change of Farming and Green Lands into Settlements in Semarang," Riptek Journal Vol. 6, No.1, pages 1-9, 2012.

12. Suryanto, 2007. The Support Capacity of the Watershed Environment for Development of Settlement Area (A Case Study of the Beringin Watershed of Semarang). Semarang: the PostGraduate Program of Universitas Diponegoro.

13. Tikno, S. 1996. The Application of ANSWERS Model to Predict the Surface Current and Sediments in Cibarengkok - Cimuntur subwatershed in West Java. A Post-Graduate Thesis of IPB. Bogor.

14. S. Adi, "The Characteristics of Flash Flood Disasters in Indonesia," A Science and Technology Journal of Indonesia Vol. 15, No. 1, pages 42-51, April 2013.

15. S. Wahyuni, Marzuki, D. Pujiastuti, L.F Sani, dan A. Rahayu, "A Study of Meteorological Conditions on Flash Flood in Padang on 24 July 2012," A Physics Journal of Unand Vol. 4, No. 4, October 2015, ISSN: 2302-8491.

16. C. Asdak. 2001. The Hydrology and the Watershed Management. Gajah Mada University Press. Yogyakarta.

17. Van Zuidam R.A., F.I. Cancelado. 1979. Terrain Analysis And Classification Using Aerial Photograph. International Institute for Aerial Survey and Earth Science. The Netherlands. 